Orijinal araştırma (Original article)

\title{
Mortality effects of eicosanoid biosynthesis inhibitors on Spodoptera littoralis larvae co-injected with the bacteria, Serratia marcescens $^{1}$
}

\author{
Eikosanoid biyosentezi inhibitörleri Serratia marcescens bakterisi ile birlikte Spodoptera \\ littoralis larvalarına uygulandığında larvalar üzerindeki ölüm etksi
}

\section{Hasan TUNAZ ${ }^{2^{*}} \quad$ Mustafa KÜSEK ${ }^{2}$}

\begin{abstract}
Summary
The first step of the cellular defense reactions to bacterial, fungal and some viral infections in insects is nodulation. We posed the hypothesis that Spodoptera littoralis, expresses melanoic nodulation reactions to bacterial challenge and that injecting $S$. littoralis larvae with eicosanoid biosnthesis inhibitors (EBIs) plus bacteria would increase larval mortality. Injecting larvae with EBIs, immediately before intrahemocoelic injections of the bacterium, Serratia marcescens, sharply reduced the nodulation response to bacterial challenges. Separate treatments with specific inhibitors including dexamethasone (a phospholipase $A_{2}$ inhibitor), indomethacin, naproxen, ibuprofen, (cyclooxygenase inhibitors), esculetin (a lipoxygenase inhibitor) and Phenidone (dual cyclooxgenase/lipoxygenase inhibitor) impaired the ability of $S$. littoralis to form nodules in reaction to bacterial challenge. All concentrations of $S$. marcescens alone, applied to $S$. littoralis, caused low mortality of the larvae. However, an increased mortality of the larvae was seen when S. marcescens was co-injected with the EBls with different modes of action. These findings support our hypothesis that virulent effects of entomopathogenic bacteria can be increased when $S$. littoralis immune systems were suppressed.
\end{abstract}

Keywords: Insect cellular immunity, nodulation, eicosanoid, bacteria, Spodoptera littoralis

\section{Özet}

Böceklerde bakeri, fungus ve bazı virüs hastalıklarına karşı oluşan hücresel bağışıklıklardan ilki nodülasyon reaksiyonudur. Bu çalışmada Spodoptera littoralis larvalarında Serratia marcescens bakterisine karşı oluşan nodülasyon reaksiyonu, bakterinin larvalar üzerindeki ölüm etkisi ve bakteri ile birlikte eiokosanoid biyosentezi inhibitörleri larvalara uygulandığında larvaların ölüm oranını etkileyip etkilemeyeceği test edilmiştir. S. littoralis larvalarına bakteri uygulamasında hemen önce eiokosanoid biyosentezi inhibitörleri enjekte edildiğinde böceklerede bakteriye karşı oluşan nodül sayısında önemli derecede azalma olmuştur. Tüm $S$. Marcescens bakteri konsantrasyonları larvalara tek başına uygulandığında düşük oranda larva ölümü ortaya çıkmıştır. Diğer taraftan $S$. marcescens bakterisi ile birlikte eikosanoid biyosentezi inhibitörleri S. littoralis larvalarına uygulandığında larvalar üzerindeki ölüm oranı yalnız bakteri uygulanan larvalara oranla önemli derecede yükselmiştir. Bu bulgular böceklerin bağışıklık sistemi baskı altına alındığında, S. marcescens bakterisinin entomopatojen etkisinin arttığını göstermiştir.

Anahtar sözcükler: Böcek hücresel bağışıklığı, nodülasyon, eikosanoid, bakteri, Spodoptera littoralis

\footnotetext{
${ }^{1}$ This study was supported by The Scientific and Technological Research Council of Turkey (TUBiTAK Project no: 1100159)

${ }^{2}$ KSÜ, Faculty of Agriculture, Plant Protection Department, Kahramanmaraş/TURKEY

* Sorumlu yazar (Corresponding author) e-mail: htunaz@ksu.edu.tr

Alınış (Received):12.12.2014 Kabul ediliş (Accepted): 17.03.2015 Çevrimiçi Yayın Tarihi (Published Online): 06.04.2015
} 


\section{Introduction}

Insect defense systems to microbial infection produce humoral and hemocytic (cellular) reactions (Gillespie et al., 1997; Stanley, 2000; Satyavathi et al., 2014; Stanley \& Kim, 2014). Humoral reactions, antibacterial proteins, such as cecropins, attacins, diptericins, and defensins, take hours for their full expression (Leulier et al., 2003; Stanley \& Miller, 2006). On the other hand, hemocytic responses are very quick, typically occur within minutes of an infection cycle and involve direct interactions between circulating hemocytes and infecting microbes (Stanley \& Miller, 2006; Satyavathi et al., 2014). Specific cellular defense mechanisms include phagocytosis, nodulation and encapsulation (Strand, 2008).

Eicosanoids are oxygenated metabolites of arachidonic acid and two other polyunsaturated fatty acids, the structures and biosynthesis of which are outlined elsewhere (Stanley, 2000; Stanley \& Kim, 2014). Eicosanoids are very well understood in the contexts of human and animal medicine, where they mediate many pathophysiological events, such as inflammation. Eicosanoids are also important for many actions in invertebrates, as reviewed (Stanley, 2000; Stanley \& Kim, 2014).

Stanley-Samuelson et al. (1991) first time showed that eicosanoids mediate one or more cellular reactions responsible for clearing bacterial infections from hemolymph circulation. After this work, more detailed research was done to determine which of the several cellular defense reactions depend on eicosanoid biosynthesis. Miller et al. (1994) hypothesized that eicosanoids mediate nodulation reactions to bacterial infections. After these findings, Stanley and his colleagues developed the hypothesis that eicosanoids mediate nodulation reactions to bacterial infections in most, if not all, insect species, now known as the eicosanoid hypothesis (Stanley, 2000). Several research groups have tested the hypothesis for many insect species, as summarized in reviews (Stanley, 2006; Stanley \& Miller, 2006; Stanley \& Kim, 2014). All experimental work has strongly supported the idea.

Howard et al. (1998) tested the influence of bacterial species on nodule formation in insects. Their result showed that nodulation intensity varies according to the species of infecting bactaria. Mandato et al. (1997) found that cell spreading, a distinct phase of nodulation, and phagocytosis are mediated by eicosanoids in wax moths, Galleria mellonella. The eicosanoid hypothesis is also supported by another line of work on humoral immunity. Morishima et al. (1997) found that biosynthesis of anti-bacterial proteins also depends on eicosanoids in the silkworm, Bombyx mori. The other role of eicosanoids in insect cellular immunity were tested by Dean et al. (2002) and Lord et al. (2002). They suggested that besides bacteria, eicosanoids mediate Manduca sexta cellular response to the fungal pathogens, Beauveria bassiana and Metarhizium anisopliae. These findings uniformly support the eicosanoid hypothesis. Connick et al. (2001) tested the role of eicosanoid biosynthesis inhibitors when co-applied with pathojen bacteria, Serratia marcescens for insect pest control. Their results showed that increased mortality of the termites, Coptotermes formosanus was seen when the bacteria were co-applied with eicosanoid biosytnhesis inhibitors. Similarly, Tunaz (2006) tested influence of different fungal species on nodule formation and on mortality of Pieris brassicae larvae and to determine whether injecting $P$. brassicae larvae with EBls plus fungus would influence larval mortality. Again his result showed that increased and faster mortality of $P$. brassicae larvae was seen when the fungi were co-applied with eicosanoid biosytnhesis inhibitors. Moreover, Tunaz \& Küsek (2012) showed that increased mortality of Blattella germanica adults was seen when the bacteria, S. marcescens, were co-applied with eicosanoid biosytnhesis inhibitors.

Therefore, the objectives of this study were to determine influence of the bacterium, $S$. marcescens, on nodule formation and on mortality of larvae of $S$. littoralis and if injection of larvae with EBIs plus the bacterium would kill the larvae faster or higher numbers than would the bacterium alone. 


\section{Materials and Methods}

\section{Organisms}

Spodoptera littoralis were reared on a culture $(38 \mathrm{~g}$ agar, $2600 \mathrm{ml}$ distil water, $300 \mathrm{~g}$ corn flour, 120 $\mathrm{g}$ wheat embryo, $100 \mathrm{~g}$ yeast, $20 \mathrm{~g}$ casein, $14 \mathrm{~g}$ wesson salt, $8 \mathrm{~g}$ sorbic acid, $4 \mathrm{~g}$ nipagin, $600 \mathrm{mg}$ streptomisin, $18 \mathrm{~g}$ ascorbic asid and $80 \mathrm{mg}$ vitamin complex) and maintained in the laboratory at $25 \pm 2{ }^{\circ} \mathrm{C}$ and $65 \pm 5 \%$ relative humidity $(\mathrm{RH})$. The larvae (5. instars) were tested for each bioassays at $25 \pm 2{ }^{\circ} \mathrm{C}$ and $65 \pm 5 \% \mathrm{RH}$.

The pathogen used is a non-pigmented strain of an entomopathogenic bacterium, Serratia marcescens (Miller \& Stanley, 1998). The bacteria were grown in $50 \mathrm{ml}$ of nutrient agar in environmental horizontal shaker at $37^{\circ} \mathrm{C}$ and $100 \mathrm{rev} / \mathrm{min}$. The bacteria were grown at concentration of $10^{9} \mathrm{cell} / \mathrm{ml}$ and used $5 \mu \mathrm{l}$ to the each insect from different concentration of $10^{9}, 10^{8}, 10^{7}, 10^{6} \mathrm{cell} / \mathrm{ml}$.

\section{Reagents}

The phospholipase $A_{2}\left(P_{2}\right)$ inhibitor dexamethasone $\{(11 \beta, 16 \alpha)$-9- fluoro-11,17,21-trihydroxy16-methylpregna-1,4-dione\}, the cyclooxygenase inhibitors ibuprofen \{a-methyl-4(2-methylpropyl) benzeneacetic acid\}, indomethacin $\{1-\mathrm{P}$-(chlorobenzyl)-5-methoxy-2-methyl-3-indolyl-acetic acid $\}$ and naproxen $\{0-2-(6-m e t h o x y-n a p h t h y l)$ propionic acid\}, the dual cyclooxygenase and lipoxygenase inhibitor phenidone \{1-pheny-3-pryazolidinone\}, and the 5- and 12- lipoxygenase inhibitor, esculetin \{6,7dihydroxycoumarin\} were all purchased from Sigma Chemical Co. (St. Louis, MO).

\section{Influence of eicosanoid biosynthesis inhibitors on nodulation}

We divided larvae of $S$. littoralis into groups and injected individuals in each group with either the phospholipase $\mathrm{A}_{2}$ inhibitor dexamethasone, the cyclooxygenase inhibitors indomethacin, naproxen, ibuprofen, and the dual cyclooxygenase and lipoxygenase inhibitor phenidone, or lipoxygenase inhibitor esculetin, all in standard dosages of $104 \mu \mathrm{g}$ in $4 \mu \mathrm{l}$ of ethanol. Control insects were injected with $4 \mu \mathrm{l}$ of ethanol. Following injections, the larvae of the $S$. littoralis were infected with $10^{9} \mathrm{~S}$. marcescens cell in $5 \mu \mathrm{l}$ saline using a $50 \mu \mathrm{l}$ Hamilton 701 micro-syringe. Control insects were injected with $5 \mu$ l saline containing $(0.85 \% \mathrm{NaCl})$. All the injections were applied into one side of abdomen (laterally just under the cuticle) of S. littoralis larvae for injecting directly into the hemolymph circulation. Each test was replicated three times and ten larvae were used for each replicate. At 6 hour post injection (hpi), the larvae of the $S$. littoralis were anesthetized and nodulation was assessed. For nodulation assessment, larvae of the $S$. littoralis were anesthetized by chilling on ice, then their hemocoels were exposed. Melanized, brownish black nodules were counted under a stereo microscope at 45x. The nodules were distinct, and direct counting reliably reflected the extent of the nodulation response to infections. After the first counting, the alimentary canal was removed. Nodules in the previously unexposed areas and remaining internal tissues were then counted.

\section{Influence of the bacteria concentrations on mortality of $\boldsymbol{S}$. littoralis larvae}

Different concentrations $\left(10^{9}, 10^{8}, 10^{7}, 10^{6} \mathrm{cell} / \mathrm{ml}\right)$ of the bacteria were injected into one side of abdomen (laterally just under the cuticle) of $S$. littoralis larvae using a $50 \mu \mathrm{l}$ Hamilton 701 micro-syringe. The larvae of $S$. littoralis (10 larvae for each concentration of bacterial cell) were injected with different concentration of $S$. marcescens cell in $5 \mu \mathrm{l}$ saline using a $50 \mu \mathrm{l}$ Hamilton 701 micro-syringe. Control insects were injected with $5 \mu \mathrm{l}$ saline containing $(0.85 \% \mathrm{NaCl})$. Each test was replicated three times and ten larvae were used for each replicate. After injection the larvae were kept on room temperature. Mortality was assessed during the seven days after injections. Mortality was identified as the larvae unable to move when placed on their dorsal side and unable to respond to prodding. 


\section{Effects of eicosanoid biosynthesis inhibitors on mortality of $S$. littoralis larvae when co- injected with the bacteria}

Spodoptera littoralis larvae were divided into groups and individuals in each group were injected with either $\mathrm{PLA}_{2}$ inhibitor dexamethasone, three of the cyclooxygenase inhibitor, naproxen, indomethacin and ibuprofen, the dual cyclooxygenase and lipoxygenase inhibitor phenidone, or the lipoxygenase inhibitor esculetin, all in standard dosages of $104 \mu \mathrm{g}$ in $4 \mu \mathrm{l} \mathrm{EtOH}$. Control insects were injected with $4 \mu \mathrm{l}$ EtOH. Following injections, the larvae were injected with $10^{9} \mathrm{~S}$. marcescens cell. Each test was replicated three times and ten larvae were used for each replicate. After injection the larvae were kept on room temperature as described. Mortality was assessed at selected times after injections as described above.

\section{Statistical Analysis}

Data on nodulation and mortality were analyzed using the General Linear Models procedure, and mean comparisons were made using Least Significant Difference (LSD) test ( $p \leq 0.0001)$ (SAS Institute Inc., 1989).

\section{Results}

\section{Influence of eicosanoid biosynthesis inhibitors on nodulation}

Figure 1 shows that, compared to control $(\mathrm{EtOH})$ larvae of $S$. littoralis, the nodulation response to bacterial infections was significantly reduced in all experimental $S$. littoralis groups (LSD, $p<0.0001$ ). There were no significant differences among the effects of individual inhibitors.

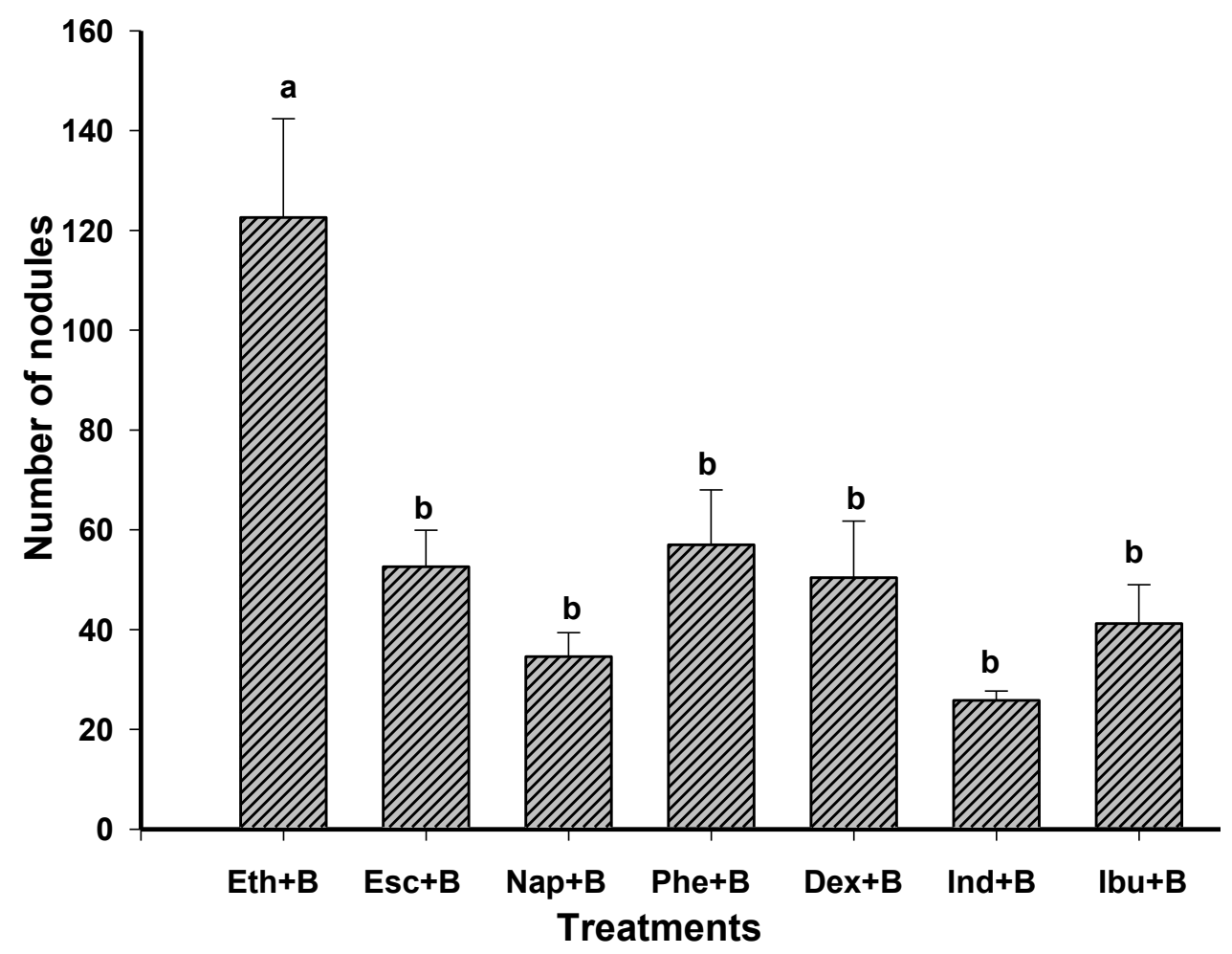

Figure 1. Effect of treating Spodoptera littoralis larvae with individual eicosanoid biosynthesis inhibitors on nodule formation in response to infections with, Serratia marcescens. Each point indicates the mean number of nodules found in each insect, and the error bars represent \pm SEM. Histogram bars with same letter are not significantly different from each other (LSD, $p \leq 0.01$ ). 


\section{Concentration-response for S. marcescens on mortality of S. littoralis larvae}

Table 1 indicates that the mortality due to $S$. marcescens cell was relatively low with all the concentrations of the bacteria. Although experimental data do not show in a strictly linear manner, we recorded increased mortality with increased concentrations of $S$. marcescens and increased time, from approximately $7 \%$ mortality on day 1 to $20 \%$ mortality on day 7 at $10^{6}$ cell/larvae and at $10^{8}$ cell/larvae, larval mortality reached a high of $30 \%$ by day 7 . At the highest concentrations, $10^{8}$ and $10^{9}$ cell/larvae, we recorded $23-30 \%$ mortality after 7 days, which is significanly diffrent (LSD, $p<0.0001)$ than mortality of the control larvae (3\% mortality by day 7 ).

Table 1. The influence of increasing concentration of Serratia marcescens cell on \% mortality of Spodoptera littoralis with respect to time (days) $( \pm$ standart error)

\begin{tabular}{|c|c|c|c|c|c|c|c|}
\hline \multirow{2}{*}{ Bacterial concentration } & \multicolumn{7}{|c|}{ Mortality (\%) in Time } \\
\hline & $1^{\text {st }}$ day & $2^{\text {nd }}$ day & $3^{\text {rd }}$ day & $4^{\text {th }}$ day & $5^{\text {th }}$ day & $6^{\text {th }}$ day & $7^{\text {th }}$ day \\
\hline $10^{9} \mathrm{cell} / \mathrm{ml}$ & $0 \pm 0^{\mathrm{a}}$ & $6.6 \pm 6.6^{\mathrm{ab}}$ & $6.6 \pm 6.6^{\mathrm{ab}}$ & $10 \pm 5.7^{\mathrm{ab}}$ & $10 \pm 5.7^{\mathrm{ab}}$ & $13.3 \pm 3.3^{\mathrm{b}}$ & $23.3 \pm 13.3^{b}$ \\
\hline $10^{8} \mathrm{cell} / \mathrm{ml}$ & $6.6 \pm 6.6^{a}$ & $13.3 \pm 6.6^{b}$ & $13.3 \pm 6.6^{b}$ & $16.6 \pm 8.8^{b}$ & $16.6 \pm 8.8^{\mathrm{b}}$ & $20 \pm 5.7^{b}$ & $30 \pm 11.5^{\mathrm{b}}$ \\
\hline $10^{7} \mathrm{cell} / \mathrm{ml}$ & $0 \pm 0^{\mathrm{a}}$ & $3.3 \pm 3.3^{\mathrm{a}}$ & $3.3 \pm 3.3^{\mathrm{a}}$ & $3.3 \pm 3.3^{\mathrm{a}}$ & $3.3 \pm 3.3^{\mathrm{a}}$ & $6.6 \pm 3.3^{\mathrm{a}}$ & $6.6 \pm 3.3^{\mathrm{a}}$ \\
\hline $10^{6} \mathrm{cell} / \mathrm{ml}$ & $6.6 \pm 3.3^{\mathrm{a}}$ & $10 \pm 0^{b}$ & $10 \pm 0^{b}$ & $13.3 \pm 3.3^{b}$ & $16.6 \pm 6.6^{b}$ & $20 \pm 5.7^{b}$ & $20 \pm 5.7^{b}$ \\
\hline Control (saline) & $3.3 \pm 3.3^{\mathrm{a}}$ & $3.3 \pm 3.3^{\mathrm{a}}$ & $3.3 \pm 3.3^{\mathrm{a}}$ & $3.3 \pm 3.3^{\mathrm{a}}$ & $3.3 \pm 3.3^{\mathrm{a}}$ & $3.3 \pm 3.3^{\mathrm{a}}$ & $3.3 \pm 3.3^{\mathrm{a}}$ \\
\hline
\end{tabular}

* Means in the same column followed by the same letters are not significantly different $(\mathrm{P}<0.0001)$ as determined by LSD-test.

\section{Effects of co-injected bacterial cell and EBIs on mortality of S. littoralis larvae}

EBls strongly enhanced absolute mortality and the speed of kill due to bacterial challenge (Table 2). High mortality (66-93\%) obtained in larvae treated with the all inhibitors plus the concentration $\left(10^{9}\right.$ cell/larvae) of bacteria by $24 \mathrm{hpi}$. Very low mortality (0-13\%) was recorded in controls (only bacteria and $\mathrm{EtOH}+$ bacteria) at $24 \mathrm{hpi}$. Co-injections of some of EBls plus bacteria led to quite high mortality of larvae, from $87 \%$ mortality with ibuprofen to over $90 \%$ mortality with dexamethasone and esculetin by 24 $\mathrm{hpi}$, whereas the control larvae produced significantly less mortality at $24 \mathrm{hpi}(\mathrm{LSD}, \mathrm{p}<0.0001)$.

Table 2. Effect of eicosanoid biosynthesis inhibitors on\% mortality of Spodoptera littoralis larvae infected with Serratia marcescens $( \pm$ standart error)

\begin{tabular}{lcc}
\hline \multicolumn{1}{c}{$\begin{array}{c}\text { Eicosanoid biosynthesis inhibitors+bacterial } \\
\text { concentration }\end{array}$} & \multicolumn{2}{c}{ Mortality $(\%)$ in Time } \\
\cline { 2 - 3 } & 6 hours & 24 hours \\
\hline Only bacteria $\left(10^{9} \mathrm{cell} / \mathrm{ml}\right)$ & $0 \pm 0^{\mathrm{a}}$ & $0 \pm 0^{\mathrm{a}}$ \\
EtOH+ bacteria $\left(10^{9} \mathrm{cell} / \mathrm{ml}\right)$ & $0 \pm 0^{\mathrm{a}}$ & $13.3 \pm 6.6^{\mathrm{b}}$ \\
Phenidone+ bacteria $\left(10^{9} \mathrm{cell} / \mathrm{ml}\right)$ & $6.6 \pm 6.6^{\mathrm{a}}$ & $66.6 \pm 17.6^{\mathrm{c}}$ \\
Naproxen+ bacteria $\left(10^{9} \mathrm{cell} / \mathrm{ml}\right)$ & $6.6 \pm 6.6^{\mathrm{a}}$ & $80 \pm 11.5^{\mathrm{cd}}$ \\
Esculetin+ bacteria $\left(10^{9} \mathrm{cell} / \mathrm{ml}\right)$ & $6.6 \pm 6.6^{\mathrm{a}}$ & $93.3 \pm 6.6^{\mathrm{d}}$ \\
Dexamethasone+ bacteria $\left(10^{9} \mathrm{cell} / \mathrm{ml}\right)$ & $6.6 \pm 6.6^{\mathrm{a}}$ & $93.3 \pm 6.6^{\mathrm{d}}$ \\
Indomethacin+bacteria $\left(10^{9} \mathrm{cell} / \mathrm{ml}\right)$ & $0 \pm 0^{\mathrm{a}}$ & $73.3 \pm 6.6^{\mathrm{c}}$ \\
Ibuprofen+ bacteria $\left(10^{9} \mathrm{cell} / \mathrm{ml}\right)$ & $6.6 \pm 6.6^{\mathrm{a}}$ & $86.6 \pm 13.3^{\mathrm{cd}}$ \\
\hline
\end{tabular}

\footnotetext{
* Means in the same column followed by the same letters are not significantly different $(P<0.0001)$ as determined by LSD-test.
} 


\section{Discussion}

The data reported in this paper strongly support the idea that EBIs significantly increased insect larval mortality due to pathogenic bacterial challenge. First, six different eicosanoid biosynthesis inhibitors significantly reduced nodulation when compared to control treatments. Second, relative to control larvae, the bacteria caused relatively low larval mortality. Moreover, treating larvae with any of six EBIs substantially increased mortality due to bacterial challenge. We infer from these data that disabling immune signaling by inhibiting eicosanoid synthesis renders insects unable to protect themselves from bacterial challenge and that the lack of immune protection is lethal.

The idea that eicosanoids mediate insect cellular immunity was first suggested by StanleySamuelson et al. (1991). They showed that when eicosanoid biosynthesis is inhibited by EBIs, M. sexta larvae could not clear the pathogenic bacterium, S. marcescens from their hemolymph. More important, this situation increased insect mortality. Since after this first paper, several laboratory groups have indicated eicosanoids are involved in nodulation formation (Stanley, 2006; Stanley \& Miller, 2006; Stanley \& Kim, 2014). There is now considerable evidence for the involvement of eicosanoids in insect immune reactions to bacteria, fungal, protozoan and parasitoid challenge in a wide range of insects. Dean et al. (2002) and Lord et al. (2002) tested the hypothesis that eicosanoids mediate nodulation reactions to fungal infection in $M$. sexta. They found that eicosanoids act in $M$. sexta nodulation response to $B$. bassiana and M. anisopliae. Connick et al. (2001) suggested that there were synergestic effects of EBls with the bacterium, S. marcescens on mortality of termites; Coptotermes formosanus. Similarly, Tunaz (2006) tested influence of different fungal species on nodule formation and on mortality of $P$. brassicae larvae and to determine whether injecting $P$. brassicae larvae with EBIs plus fungus would influence larval mortality. Again his result showed that increased and faster mortality of $P$. brassicae larvae was seen when the fungi were co-applied with eicosanoid biosytnhesis inhibitors. Additionally, Tunaz \& Küsek (2012) showed that increased mortality of $B$. germanica adults was seen when the bacteria, $S$. marcescens were co-applied with eicosanoid biosytnhesis inhibitors. Similar to these works, we suggested that there were synergestic effects of EBls with the bacterium, S. marcescens on mortality of $S$. littoralis. The bacterial concentration-response experiment ( $S$. marcescens) on larval mortality showed that mortality was relatively low without EBIs.

The pharmacological chemicals we used inhibit different eicosanoid biosynthetic pathways in mammals. Dexamethasone inhibits phospholipase $A_{2}$ which releases arachidonic from membrane phospholipids; naproxen, indomethacin and ibuporfen inhibit cyclooxygenase; esculetin inhibits lipoxygenase; and phenidone inhibits both cyclooxygenase and lipoxygenase (Stanley, 2000). Hence, because all the inhibitors we tested enhanced the susceptibility of $S$. littoralis to the injected bacteria, it is possible that both cyclooxygenase and lipoxygenase pathways are involved in mediating the immunomodulatory effects of eicosanoids in this insect. Finally, the results supported the hypothesis. Eicosanoid biosynthesis inhibitors led to increased larval mortality, which supports the concept that biological control programs can be enhanced by engineering gene-silencing constructs into crop plants.

\section{Acknowledgement}

The authors thank the Scientific and Research Council of Turkey (Ankara) for financial support. 


\section{References}

Connick, W.J., W.L.A. Osbring, M.S. Wright, K.S. Williams, D.J. Daigle, D.L. Boykin \& A.R. Lax, 2001. Increased mortality of Coptotermes formosanus (Isoptera: Rhinotermitidae) exposed to eicosanoid biosynthesis inhibitors and Serratia marcescens (Eubacteriales: Enterobactericeae). Environmental Entomology. 30:449-455.

Dean, P., J.C. Gadsden, E.H. Richards, J.P. Edwards, A.K. Charnley \& S.E. Reynolds, 2002. Modulation by eicosanoid biosynthesis inhibitors of immune responses by the insect Manduca sexta to the pathogenic fungus Metarhizium anisopliae. Journal of Invertebrate Pathology. 79: 93-101.

Gillespie, J.A., M.R. Kanaost \& T. Trenzcek, 1997. Biological mediators of insect imunity. Annual Review of Entomology, 47: 611-643.

Howard, R.W., J.S. Miller \& D.W. Stanley, 1998. The influence of bacterial species and intensity of infections on nodule formations in insect. Journal of Insect Physiology. 44: 157-164.

Leulier, F., C. Parquet, S. Pili-Floury, J.H. Ryu, M. Caroff, W.J. Lee, D. Mengin-Lecreulx \& B. Lemaitre, 2003. The Drosophila immune system detects bacteria through specific peptidoglycan recognition. Nature Immunology 4: 478-484.

Lord, J.J., S. Anderson \& D.W. Stanley, 2002. Eicosanoids mediate Manduca sexta cellular response to the fungal pathogen Beauveria bassiana: A role for the lipoxygenase pathway. A.R.C. Unit of Reproductive Physiology and Biochemistry. 51: 46-54.

Mandato, C.A,. W.L. Diehl-Jones, S.J. Moore \& R.G.H. Downer, 1997. The effects of eicosanoid biosynthesis inhibitors on prophenoloxidase activation, phagocytosis and cell spreading in Galleria mellonella. Journal of Insect Physiology. 43: 1-8.

Miller, J.S., T. Nguyen \& D.W. Stanley-Samuelson, 1994. Eicosanoids mediate insect nodulation responses to bacterial infections. Proceedings of the National Academy of Sciences of the United States of America. 91: 12418-12422.

Miller, J.S. \& D.W. Stanley, 1998. "The Nodule Formation Reaction to Bacterial Infection: Assessing the Role of Eicosanoids, 265-270". In: Techniques in Insect Immunity (Eds: A. Wiesner, A. G. Dumphy \& V. J. Marmaras). SOS publications, Fair Haven, Cornell University NJ. 304 pp.

Morishima, I., Y. Yamano, K. Inoue \& N. Matsuo, 1997. Eicosanoids mediate induction of immune genes in the fat body of the silkworm, Bombyx mori. FEBS Letters, 419: 83-86.

SAS Institute Inc. 1989. SAS/STAT ${ }^{R}$ User's Guide, Version 6, $4^{\text {th }}$ Ed., vol 2. SAS Institute Inc., Cary, NC.

Satyavathi, V.V., A Minz \& J. Nagaraju, 2014. Nodulation: An unexplored cellular defense mechanism in insects. Cell. Sign. 26: 1753-1763.

Stanley-Samuelson, D.W., E. Jensen, K.W. Nickerson, K. Tiebel, C.L. Ogg \& R.W. Howard, 1991. Insect immune response to bacterial infection is mediated by eicosanoids. Proceedings of the National Academy of Sciences of the United States of America. 88: 1064-1068.

Stanley, D.W. 2000. Eicosanoids in Invertebrate Signal Transduction Systems. Princeton University Press, Princeton, NJ.

Stanley, D.W. 2006. Prostaglandins and other eicosanoids in insects: Biological significance. Annual Review of Entomology. 51:25-44.

Stanley, D.W. \& J.S. Miller, 2006. Eicosanoid actions in insect cellular immune functions. Entomologia Experimentalis et Applicata. 119: 1-13.

Stanley, D.W. \& Y. Kim, 2014. Eicosanoid signaling in insects: from discovery to plant protection. Critical Reviews in Plant Sciences, 33: 20-63.

Strand, M.R. 2008. "Insect Hemocytes and Their Role in Immunity, 25-47". In: Insect Immunology (Ed: N.E. Beckage), Academic Press, Elsevier, Amsterdam. 360 pp.

Tunaz, H. 2006. Eicosanoid biosynthesis inhibitors influence mortality of Pieris brassicae larvae co-injected with fungal conidia. A.R.C. Unit of Reproductive Physiology and Biochemistry. 63: 93-100.

Tunaz, H. \& M. Küsek, 2012. “The role of eicosanoid biosynthesis inhibitors on mortality of Blattella germanica adults co-injected with the bacteria; Serratia marcescens, 29-32". Second International Symposium of Biopesticides and Ecotoxicological Network (September 24-26, 2012 Bangkok), Thailand. 